\title{
FORMULASI SEDIAAN KRIM DAUN BINAHONG (Anredera cordifolia (Ten.) Steenis): KAJIAN KARAKTERISTIK FISIKA KIMIA DAN UJI IRITASI KULIT
}

\author{
Elya Zulfa $^{1^{*}}$, Liya Lailatunnida ${ }^{1}$, Mimik Murukmihadi $^{2}$ \\ ${ }^{1}$ Fakultas Farmasi, Universitas Wahid Hasyim \\ Jl. Menoreh Tengah X/22, Sampangan, Semarang 50236. \\ ${ }^{1}$ Fakultas Farmasi, Universitas Gajah Mada \\ Sinduadi, Mlati, Kabupaten Sleman, Daerah Istimewa Yogyakarta 55281 \\ "Email: elya@unwahas.ac.id
}

\begin{abstract}
Abstrak
Ekstrak etanol daun binahong (EEDB) secara empiris digunakan sebagai pengobatan luka. Penelitian ini bertujuan untuk mengetahui pengaruh variasi konsentrasi EEDB pada sediaan krim terhadap sifat fisik kimia krim dan uji iritasi.Penelitian ini diawali dengan pembuatan ekstrak etanol $70 \%$ dengan metode maserasi. Ekstrak dibuat sediaan krim dengan basis vanishing krim dengan variasi konsentrasi ekstrak yaitu F I (5\%), F II (10\%), dan F III (20\%), F O (control basis). Data uji organoleptis dan uji homogenitas dianalisis secara deskriptif. Pengukuran $\mathrm{pH}$, uji daya sebar, uji daya lekat, dan viskositas dianalisis secara statistik regresi linier. Sedangkan uji iritasi primer dianalisis menggunakanKruskal Wallis karena data tidak terdistribusi normal maka dilanjutkan dengan uji Mann Whitney. Hasil penelitian menunjukkan bahwa krim berwarna hijau tua, lembut, bau khas armatik, homogen dan sesuai pH kulit. kenaikan konsentrasi ekstrak berpengaruh meningkatkan viskositas dan daya lekat, tetapi menurunkan daya sebar. Sетиа formula memiliki indeks iritasi yang sama yaitu hanya sedikit mengiritasi $(<2)$.
\end{abstract}

Kata kunci: daun binahong, krim, uji iritasi, vanishing cream

\section{PENDAHULUAN}

Salah satu tumbuhan herbal yang memiliki khasiat sebagai bahan obat ialah tanaman binahong (Anredera cordifolia (Ten.) Steenis). Daun Binahong mengandung alkaloid, saponin dan flavanoid yang memiliki aktivitas sebagai antibakteri (Rochani, 2009). Saponin memiliki kemampuan sebagai antiseptik yang berfungsi membunuh atau mencegah pertumbuhan mikroorganisme yang biasa timbul pada luka sehingga luka tidak mengalami infeksi berat. Flavonoid memiliki efek yang kuat sebagai anti oksidan, merangsang produksi oksidasi nitrit yang dapat melebarkan pembuluh darah. Flavonoid juga dapat menginhibisi pertumbuhan fibroblast sehingga memberikan keuntungan pada proses penyembuhan luka. Aktivitas fibroblast yang berlebihan dapat menghambat proses penyembuhan luka. Flavonoid dapat menginduksi poliferasi sel sehingga dapat mempercepat penyembuhan luka (Robinson, 1995). Khunaifi., (2010) telah meneliti khasiat daun binahong terhadap bakteri Staphylococcus aureus dan Pseudomonas aeruginosa yang menyatakan bahwa konsentrasi hambat minimum ekstrak etanol daun binahong (EEDB) terhadap bakteri Staphylococcus aureus adalah pada konsentrasi $25 \%$ yang setara dengan $250 \mathrm{mg} / \mathrm{mL}$, dan pada bakteri Pseudomonas aeruginosa pada konsentrasi $50 \%$ setara dengan $500 \mathrm{mg} / \mathrm{mL}$. Konsentrasi bunuh minimum ekstrak etanol daun binahong terhadap Staphylococcus aureus adalah pada konsentrasi $50 \%$ setara dengan $500 \mathrm{mg} / \mathrm{ml}$, sedangkan pada bakteri Pseudomonas aeruginosa pada konsnetrasi $100 \%$ setara dengan $100 \mathrm{mg} / \mathrm{mL}$. Penelitian Paju et al., (2013) menghasilkan sediaan salep ekstrak etanol daun binahong efektif sebagai obat luka akibat infeksi bakteri Staphylococcus aureus pada konsentrasi $20 \%$.

Mengingat luasnya penggunaan eksrak daun binahong secara topikal, diharapkan sediaan tidak berpotensi menimbulkan iritasi primer. Iritasi primer kulit penting dilakukan pada semua sediaan topikal atau sediaan yang digunakan pada kulit, untuk mengetauhi tingkat kemampuan krim mengiritasi kulit sekaligus untuk mengetauhi tingkat keamanan produk sediaan topikal lain yang dibuat (Lu, 1995). Sebelum dipasarkan krim harus melalui 
serangkaian uji salah satunya uji efektifitas dan keamanan yang merupakan hal penting sebelum suatu sediaan dipasarkan.

Ekstrak etanol daun binahong agar mudah digunakan diformulasikan pada sediaan krim dengan tipe vanishing creamyang berfungsi sebagai krim penyejuk, memberikan rasa dingin dan nyaman pada kulit luka bakar, lapisan berminyak/film yang tertinggal pada kulit membuat efek obat yang dioleskan tertahan lama dikulit. Uji iritasi kulit penting dilakukan untuk mengetahui keamanan krim ekstrak etanol daun binahong jika digunakan pada kulit manusia. Sehingga efektifitas ekstrak etanol daun binahong dapat tercapai dengan baik misalnya untuk menyembuhkan luka, menyembuhkan luka infeksi bakteri, maupun menyembuhkan luka bakar.

\section{METODOLOGI}

Bahan

Bahan utama yang digunakan dalam penelitian ini adalah daun binahong (Anredera cordifolia (Ten.) Steenis) yang diperoleh dari UD.Jamu Sleman Jogja. Bahan lain yang digunakan dalam penelitian ini kualitas farmasi yaitu alkohol 70\% (P.A),paraffin liquidum, Asam stearat, Adeps lanae, TEA, Nipagin, Nipasol, dan Aquadest.
Alat

Seperangkat alat gelas, oven precision vacuum oven hitemp, moisture content balance, ayakan mesh 25 , blander, timbangan elektronik Ohaust AR 2140 dengan kepekaan 0,1 mg, pot salep, cawan porselin, mortir dan stamfer, waterbath. Alat uji homogenitas berupa object glass, alat uji daya sebar berupa kaca arlogi, beban $50 \mathrm{~g}, 100 \mathrm{~g}$, dan $1 \mathrm{~kg}$, alat uji daya lekat berupa stopwatch dan beban $80 \mathrm{~g}$, pH-meter digital (Handylab pH 11/SET, Schott Instruments, viskotester DV-E Viskotester Brook Field., rotor 4.

\section{Pembuatan Ekstrak Etanol Daun Binahong}

Ekstraksi daun binahong dengan metode maserasi yaitu merendam serbuk simplisia dalam cairan penyari dengan perbandingan 1:10. Proses maserasi menghasilkan maserat sebanyak $12 \mathrm{~L}$ yang kemudian diuapkan menggunakan rotary evaporator dengan suhu $37-39^{\circ} \mathrm{C}$ untuk mendapatkan ekstrak kental.Total ekstrak kental yang diperoleh adalah 550 gram dari serbuk simplisia sebanyak 987 gram.

\section{FormulaKrim Ekstrak Etanol Daun Binahong}

Formula krim yang digunakan dapat dilihat pada Tabel I. Sediaan krim yang digunakan pada penelitian dapat dilihat pada Tabel 1.

Tabel 1. Formulaacuanbasis krimekstraketanoldaunkirinyuh (Yenti 2011)

\begin{tabular}{|c|c|c|c|c|c|}
\hline \multirow[t]{2}{*}{ No } & \multirow[t]{2}{*}{ Bahan } & \multicolumn{2}{|c|}{ Formula } & \multirow{2}{*}{$\begin{array}{l}\mathbf{m} / \mathbf{a} \\
\text { F II }\end{array}$} & \multirow{2}{*}{$\begin{array}{l}\text { (gram) } \\
\text { F III }\end{array}$} \\
\hline & & F O & F I & & \\
\hline 1. & Ekstrak Etanol Daun kirinyuh & - & $2,5 \%$ & $5 \%$ & $10 \%$ \\
\hline 2. & Paraffin liquidum & 25 & 25 & 25 & 25 \\
\hline 3. & Asam stearate & 14,5 & 14,5 & 14,5 & 14,5 \\
\hline 4. & Adeps lanae & 3 & 3 & 3 & 3 \\
\hline 5. & TEA & 1,5 & 1,5 & 1,5 & 1,5 \\
\hline 6. & Nipagin & 0,1 & 0,1 & 0,1 & 0,1 \\
\hline 7. & Nipasol & 0,05 & 0,05 & 0,05 & 0,04 \\
\hline 8. & Aquadest ad & 100 & 100 & 100 & 100 \\
\hline
\end{tabular}


Tabel 2. Formulabasis krimekstraketanoldaunbinahong dengan berbagai konsentrasi ekstrak

\begin{tabular}{llllll}
\hline \multirow{2}{*}{ No } & & & Formula & m/a & (gram) \\
\cline { 3 - 6 } & & F 0 & F I & F II & F III \\
\hline 1. & Ekstrak Etanol Daun binahong & - & $5 \%$ & $10 \%$ & $20 \%$ \\
\hline 2. & Paraffin liquidum & 25 & 25 & 25 & 25 \\
\hline 3. & Asam stearate & 14,5 & 14,5 & 14,5 & 14,5 \\
\hline 4. & Adeps lanae & 3 & 3 & 3 & 3 \\
\hline 5. & TEA & 1,5 & 1,5 & 1,5 & 1,5 \\
\hline 6. & Nipagin & 0,1 & 0,1 & 0,1 & 0,1 \\
\hline 7. & Nipasol & 0,05 & 0,05 & 0,05 & 0,04 \\
\hline 8. & Aquadest ad & 100 & 100 & 100 & 100 \\
\hline
\end{tabular}

\section{Keterangan:}

F 0 : krim tanpa penambahan EEDB

F I : krim dengan penambahan EEDB 5\%

F II : krim dengan penambahan EEDB 10\%

F III: krim dengan penambahan EEDB 20\%

\section{Pembuatan Krim Ekstrak Etanol Daun Binahong}

Pembuatan Krim Fase Minyak yaitu, paraffin liquidum, asam stearat, adeps lanae di masukkan ke dalam cawan porselin, dilebur di atas waterbath pada suhu $60^{\circ}-70^{\circ} \mathrm{C}$ sampai lebur; Pembuatan fase air yaitu Nipagin, Nipasol, TEA, dan Aquadest dimasukkan kea. dalam beaker glass, kemudian dipanaskan di atas waterbath pada suhu $60^{\circ}-70^{\circ} \mathrm{C}$ sampai lebur; Fase minyak dituang ke dalam mortir dalam keadaan hangat, kemudian diaduk sampai homogen; Fase air ditambahkan sedikit demi sedikit sambil diaduk perlahan-lahan hingga terbentuk massa krim;Ekstrak kental daun binahong dibuat dengan metode maserasib. dimasukkan ke dalam massa krim;Ekstrak kental daun binahong dan basis krim kemudian diaduk sampai homogen sampai tidak ada bulirbulir pada massa krim; Krim dimasukkan ke dalam wadah.

\section{Uji Karakteristik Fisik Krim Ekstrak Etanol} Daun Binahong

Uji karakteristik fisik terdiri dari uji organoleptis dan homogenitas, yang diamati meliputi tekstur, bau, rasa, dan homogenitas krim.

Uji Daya Sebar Krim

Krim dilekatkan secukupnya di tengah alat dengan diameter $15 \mathrm{~cm}$, kaca yang satu diletakkan di atasnya dibiarkan selama 1 menit. Selanjutnya diameter

krim yang menyebar diukur, ditambahkan 50 gram beban tambahan, diamkan selama 1 menit, dan diukur diameter krim yang menyebar. Hal tersebut dilakukan berulang sampai didapat diameter sebar yang konstan.

\section{Uji Daya Lekat Krim}

Dengan dua buah object glass, stopwatch, anak timbang gram, lekatkan krim secukupnya pada tiap object glass, kemudian ditekan dengan beban $1 \mathrm{~kg}$ selama 5 menit. Selanjutnya pasang object glass pada alat tes, lalu lepaskan beban seberat 80 gram dan catat waktunya hingga kedua objek tersebut terlepas.

. Uji Viskositas Krim

Viskositas sediaan krim diukur menggunakan DV-E Viskotester Brook Field., rotor 4. Sediaan sebanyak 150 gram dimasukkan ke dalam wadah, kemudian dipasang spindel dan rotor dijalankan. Hasil viskositas dicatat setelah viskotester menunjukkan angka yang stabil.

Pengukuran $\mathrm{pH}$

Pengukuran $\mathrm{pH}$ dengan menggunakan $\mathrm{pH}$ meter dengan cara mencelupkan indikator $\mathrm{pH}$ kedalam sediaan krim, kemudian didiamkan sampai alat menunjukkan angka $\mathrm{pH}$ yang didapat. 


\section{Uji Iritasi Primer Kulit}

Uji iritasi primer dilakukan pada setiap formula krim yang dibuat berdasar prosedur berikut:

a. Pemilihan Hewan Uji

Hewan uji yang akan digunakan adalah kelinci jenis Australi dengan kriteria inklusi yaitu: kelinci putih lokal, berjenis kelamin jantan, sehat, tidak memiliki luka pada kulit punggungnya, usia sekitar 2-4 bulan. Sedangkan kriteria eksklusi yaitu: kelinci sakit (diare, demam, memiliki jamur atau kutu), kelinci berkulit sensitif, serta kelinci memiliki luka pada kulitnya.

b. Pencukuran Hewan Uji

Bulu pada punggung kelinci dicukur dengan hati-hati untuk mendapatkan area uji yang diinginkan yang akan digunakan untuk uji iritasi primer. Setalah bulu punggung kelinci dicukur habis kemudian didiamkan selama 24 jam sebelum pemejanan senyawa uji. Punggung kelinci yang akan dioleskan senyawa uji ditandai menggunakan spidol dengan ukuran $1 \mathrm{x} 1$ inci kulit $(2,54 \mathrm{~cm} \times 2,54 \mathrm{~cm})(\mathrm{Lu}, 1995$; OECD, 2002).

c. Pemejanan Senyawa Uji

Sebelum dioleskan, kulit kelinci dibersihkan pelan-pelan menggunakan kapas bersih yang dibasahi akuades. Setelah itu oleskan krim sebanyak 0,5 gram pada kulit kelinci dan ditutup dengan kassa steril dan plaster selama 24 jam. Setelah itu hewan uji dikembalikan ke kandangnya dan hari berikutnya pada jam yang sama, plester dibuka dan kulit hewan uji dibersihkan dengan akuades dari sisa senyawa uji yang menempel. Gejala yang diamati yaitu iritasi primer yang berupa eritema dan edema selama 24, 48, dan 72 jam (OECD, 2002).

d. Pembacaan Hasil dan Pemberian Scoring Pada waktu pengamatan gejala toksik iritasi primer, hal yang diamati adalah adanya eritema dan edema. Kemudian dari tingkat iritasi yang timbul diberi skor sesuai Tabel III. Kemudian dilakukan perhitungan indeks iritasi primer dengan rumus, yaitu:

Eri 24 jam+eri 48 jam+eri 72 jam+ede 24 jam+ede 48 jam+ede 72 jam

Keterangan: Eri $=$ eritema $\quad$ Ede $=$ edema

Penggolongan potensi iritasi produk indeks iritasi primer yang dihitung digunakan sebagai dasar untuk mengelompokkan suatu senyawa uji berdasarkan kemampuannya mengiritasi kulit.

Tabel 3. Evaluasi Reaksi Kulit (Lu, 1995)

\begin{tabular}{lr}
\hline 1. & Skor \\
& \\
\hline Tanpa eritema & 0 \\
Eritema sangat sedikit (hampir tidak ada) & 1 \\
Eritema berbatas jelas & 2 \\
Eritema moderat sampai berat & 3 \\
Eritema berat (merah bit) sampai sedikit membentuk kerak (luka) & 4 \\
& \\
\hline Total skor eritema yang mungkin & 4 \\
\hline Pembentukan edema & Skor \\
\hline Tanpa edema & 0 \\
Edema sangat sedikit ( hampir tidak tampak) & 2 \\
Edema sedikit (tepi daerah berbatas jelas) & 3 \\
Edema moderat (tepi naik kira-kira 1 mm) & 4 \\
pemejanan) (naik lebih dari 1 mm dan meluas keluar daerah & \\
\hline Total skor edema yang mungkin & 4 \\
\hline
\end{tabular}


Tabel 4. Kategori sifat mengiritasi berdasarkan rata-rata gabungan indeks iritasi primer senyawa kimia ( $\mathrm{Lu}, 1995)$

\begin{tabular}{cll}
\hline \multicolumn{2}{c}{ Indeks Iritasi Primer } & \multicolumn{1}{c}{ Golongan Senyawa } \\
\hline & $<2$ & Hanya sedikit merangsang \\
& $>5$ & Iritan moderat \\
\hline & Iritan berat \\
\hline lisis Data & primer kulit menggunakanKruskal Wallis \\
Uji organoleptik dan uji homogenitas & karena data tidak terdistribusi normal maka & dilanjutkan dengan uji Mann Whitney.
\end{tabular}
dianalisis menggunakan analisis deskriptif dengan cara mengamati bentuk, bau, warna, dan homogen atau tidak. Hasil uji $\mathrm{pH}$, daya sebar, daya lekat, dan viskositas dianalisis secara statistik korelasi regresi linier. Hasil uji iritasi primer diamati secara kualitatif melihat evaluasi reaksi kulit adanya reaksi eritema dan edema yang muncul pada kulit punggung kelinci, kemudian dilakukan perhitungan indeks iritasi primer kulit untuk mengetauhi kategori sifat iritasi primer, dan pengamatan kuantitatif adalah dengan menganalisis data indeks iritasi

\section{HASIL DAN PEMBAHASAN \\ Karakteristik fisika kimia sediaan krim EEDB}

Hasil uji karakteristik fisika kimia dapat dilihat pada Tabel V. Hasil uji organoleptis pada ke 3 formula krim menunjukkan hasil warna yang sama yaitu hijau tua, berbau khas aromatik, tekstur lembut dan homogen. Sediaan krim yang homogen mengindikasikan bahwa senyawa aktif yang ada pada ekstrak terdstribusi merata pada sediaan.

Tabel 5. Hasil Uji Karakteristik Fisika Kimia sediaan Krim EEDB

\begin{tabular}{lllllll}
\hline Homogenitas & \multicolumn{1}{c}{ Organoleptis } & $\begin{array}{l}\text { Daya } \\
\text { lekat } \\
\text { (detik) }\end{array}$ & $\begin{array}{l}\text { Daya } \\
\text { sebar } \\
\text { (cm) }\end{array}$ & $\begin{array}{l}\text { Viskositas } \\
\text { (Cps) }\end{array}$ & pH \\
\hline & Homogen & $\begin{array}{l}\text { Hijau tua, khas } \\
\text { aromatic, lembut }\end{array}$ & 16,00 & 3,25 & 236 & 6,95 \\
Hijau tua, khas & Iromatic, lembut & 18,67 & 2,52 & 253 & 7,01 \\
I & Homogen & $\begin{array}{l}\text { Hijau tua, khas } \\
\text { aromatic, lembut }\end{array}$ & 20,33 & 2,02 & 283 & 7,00 \\
\hline II & Homogeny & $\begin{array}{l}\text { F I : krim dengan penambahan EEDB 5\% } \\
\text { F II : krim dengan penambahan EEDB 10\% }\end{array}$ & & & \\
F III: krim dengan penambahan EEDB 20\%
\end{tabular}

Uji daya sebar dilakukan untuk mengetahui kemampuan basis menyebar pada permukaan kulit saat diaplikasikan. Kemampuan penyebaran basis yang baik akan memberikan kemudahan pengaplikasikan pada permukaan kulit. Selain itu penyebaran zat aktif pada kulit lebih merata sehingga efek yang ditimbulkan zat aktif lebih optimal. Pada pengujian daya sebar (Tabel V) menunjukkan bahwa ada pengaruh penambahan variasi EEDB terhadap daya sebar $(\operatorname{sig}<0,05)$, dimana adanya kenaikan konsentrasi EEDB menyebabkan penurunan daya sebar dengan nilai pengaruh sebesar $55,1 \%$.

Uji daya lekat krim dilakukan untuk mengetahui kemampuan krim melekat pada tempat aplikasinya. Daya lekat basis berhubungan dengan lamanya kontak antara basis dengan kulit dan kenyamanan pengunaan

basis. Basis yang baik mampu menjamin waktu kontak yang efektif dengan kulit. Sehingga efek dari zat aktif dapat tercapai untuk penyembuhan. Pada pengujian daya lekat secara statistic (Tabel V) menunjukkan bahwa tidak ada pengaruh variasi konsentrasi ekstrak EEDB pada daya lekat krim $($ sig $>0,05)$ daya lekat krim. Adanya kenaikan EEDB dapat meningkatkan daya lekat krim ekstrak etanol daun binahong dengan engaruh sebesar 2,6\%.

Viskositas merupakan sifat dari suatu cairan yang berhubungan dengan hambatan untuk mengalir. Viskositas suatu cairan yang 
besar akan memerlukan tekanan yang besar untuk mengalir, sehingga nilai viskositas dapat mempengaruhi kemampuan menyebar dari suatu sediaan (Ansel, 1969). Hasil pengujian viskositas menunjukkan bahwa adanya variasi EEDB memberikan pengaruh terhadap viskositas $\mathrm{krim} \quad(\mathrm{sig}<0,05)$ Kenaikan konsentrasi EEDB dalam sediaan krim maka akan meningkatkan viskositasnya dengan pengaruh sebesar $49,8 \%$.

Sediaan krim yang dibuat menghasilkan $\mathrm{pH}$ antara 6,95-7,03 yang masih berada pada kisaran $\mathrm{pH}$ kulit, sehingga sediaan krim ini aman untuk digunakan. Hal ini berarti adanya variasi konsentrasi ekstrak etanol daun binahong dapat meningkatkan $\mathrm{pH}$ krim. $\mathrm{pH} 7$ tergolong netral, tetapi berada diluar rentan $\mathrm{pH}$ kulit dan vagina. Sehingga perlu dilakukan uji iritasi terlebih dahulu sebelum diaplikasikan pada kulit yang terluka dan terinfeksi.

\section{Uji Iritasi Primer Kulit}

Pada pengujian uji iritasi digunakan hewan kelinci karena kelinci merupakan hewan yang telah digunakan secara luas untuk deteksi sifat-sifat iritan dari zat kimia (Loomis, 1978), serta memiliki kulit yang sensitif dibandingkan dengan hewan uji lainnya dan berdasarkan bulunya, bulu kelinci lebih mudah dicukur. Pada dasarnya sensitifitas kulit hewan coba sedikit berbeda dengan kulit manusia (Naitalia, 2014). Khususnya kelinci yang tingkat iritasinya sangat mudah terlihat, indeks iritasi pada manusia masih tidak bisa dipastikan apabila nilai pada hewan coba memiliki indeks iritasi ringan. Uji iritasi primer ada dua macam pengamatan yaitu pengamatan kualitatif dan pengamatan kuantitatif. Pengamatan kualitatif dilakukan dengan melihat gejala toksik iritasi primer dengan melihat timbul tidaknya eritema dan edema setelah terpejan oleh tiap formula. Kemudian dilakukan evaluasi reaksi kulit untuk mengelompokkan eritema dan edema ke dalam skor. Pengamatan kualitatif dilakukan dengan menghitung indeks iritasi primer dan melakukan analisis data secara statistik.Hasil pengamatan memperlihatkan bahwa formula dengan variasi konsentrasi ekstrak etanol daun binahong pada sediaan krim setelah pemejanan pada hewan uji, hanya sedikit mengiritasi $(<2)$. Hal ini dapat dilihat dengan adanya eritema dan edema yang muncul sesuai evaluasi reaksi kulit yang dapat dilihat pada Tabel V.

Tabel 5. Reaksi Eritema dan Edema pada Kulit Hewan Uji

\begin{tabular}{|c|c|c|c|}
\hline & Formula & Indeks & Rata-rata \\
\hline & 1 & 0,30 & 0,30 \\
\hline & 2 & 0,30 & \\
\hline & 3 & 0,30 & \\
\hline & 1 & 0,00 & 0,11 \\
\hline & 2 & 0,16 & \\
\hline & 3 & 0,16 & \\
\hline & 1 & 0,16 & 0,25 \\
\hline & 2 & 0,30 & \\
\hline & 3 & 0,30 & \\
\hline & 1 & 0,00 & 0,05 \\
\hline & 2 & 0,16 & \\
\hline & 3 & 0,00 & \\
\hline
\end{tabular}

Keterangan:

F 0 : krim tanpa penambahan EEDB

F I : krim dengan penambahan EEDB 5\%

F II : krim dengan penambahan EEDB $10 \%$

F III: krim dengan penambahan EEDB 20\%

Hasil perhitungan indeks iritasi primer menunjukkan F 0, F I, F II, dan F III merupakan golongan senyawa dengan kategori sifat mengiritasi hanya sedikit merangsang $(<2)$. Dimana $\mathrm{F} 0$ memiliki rata-rata indeks iritasi primer sebesar 0,3; F I 0,11; F II 0,25; dan F III 
0,05. Sehingga dari hasil tersebut menunjukkan bahwa formula krim ekstrak etanol daun binahong dengan basis vanishing cream bisa dikembangkan menjadi sediaan krim untuk pengobatan luka.Hasil indeks iritasi primer yang telah diuji secara statistik ANAVA memperlihatkan bahwa indeks iritasi kulit menunjukkan data yang tidak terdistribusi normal namun variasi sampel homogen, sehingga dilanjutkan dengan analisa menggunakan Kruskall Wallis dan Mann Whitney. Hasil analisa secara statistik non parametrik Mann Whitney, menunjukkan Nilai Asymp. Sig 0,034 $(<0,05)$, yang artinya hasil uji iritasi antara F I (5\%), F II (10\%), dan F III (20\%) tidak jauh berbeda dari kontrol basis (F 0) yaitu basis krim dan krim ekstrak etanol daun binahong hanya sedikit merangsang.

Penelitian serupa juga pernah dilakukan oleh Sukandar (2006) sediaan salep dan krim dengan tipe vanishing cream ekstrak daun ketapang (Terminalia cattapa L.) memberikan indeks iritasi ringan pada kulit kelinci sebesar 0,33 pada salep dan 0,70 pada krim. Hasil penelitian lain menunjukkan bahwa basis salep minyak atsiri kayu manis cina dapat menyebabkan iritasi walaupun hanya sedikit iritasi, hal ini ditunjukkan dengan indeks iritasi primer 1,8 (Megarumi, 2015).

Hasil penelitian ini menunjukkan indeks iritasi yaitu hanya sedikit mengiritasi (< 2), sehingga sedian krim ekstrak etanol daun binahong dengan basis vanishing cream bisa dilanjutkan untuk dilakukan pengujian efektifitas terhadap penyembuhan luka.

\section{KESIMPULAN}

Variasi kosentrasi ekstrak etanol daun binahong memiliki warna hijau tua pekat, bentuk semi padat dan aroma khas daun serta homogen, berpengaruh meningkatkan viskositas, daya lekat dan $\mathrm{pH}$ namun menurunkan daya sebar. Semua formula memiliki indeks iritasi yang sama yaitu hanya sedikit mengiritasi $(<2)$.

\section{SARAN}

Perlu dilakukan penelitian lebih lanjut mengenai efektivitas penyembuhan luka bakar dengan krim EEDB basis vanishing cream.

\section{DAFTAR PUSTAKA}

Depkes RI, 1986,SediaanGalenik, DepartemenKesehatan Republik Indonesia, Jakarta, 10

Departemen Kesehatan Republik Indonesia. (2008). Farmakope Herbal Indonesia. (Edisi I). Jakarta: Departemen Kesehatan Republik Indonesia. Departemen Kesehatan Republik Indonesia.

Irsan, M.A. Manggau, E. Pakki, dan U, 2013, 'Uji Iritasi Krim Antioksidan Ekstrak Biji Lengkeng (Euphoria longana Stend) pada Kulit Kelinci (Oryctolagus cuniculus)', Majalah Farmasi dan Farmakologi. 17, 55-60.

Khunaifi, M.,2010, 'Uji Aktivitas Antibakteri Ekstrak Daun Binahong (Anredera Cordifolia (Ten.) Steenis Terhadap Bakteri Staphylococcus Aureusdan Pseudomonas Aeruginosa', skripsi,Fakultas Sains dan Teknologi, Jurusan Biologi: Universitas Islam Negeri (UIN) Maulana Malik Ibrahim, Malang.

Loomis, T., 1978,Toksikologi Dasar. IKIP Semarang Press: Yogyakarta, 278.

Lu, F. C., 1995,Toksikologi Dasar, Asas, Organ Sasaran, dan Penilaian Resiko. 2nd edn. Jakarta: UI-Press, 325.

OECD, 2002,Acute Toxicity: Dermal Irritation/Corrosion. Available at: http://www.oecd/ehs/test/monos.htm (Accessed: 2 January 2017).

Paju, Niswah., Paulina V.Y.Yamlen., 2013, 'Uji Efektivitas Salep Ekstrak Daun Binahong (Anredera cordifolia (Ten.) Steenis) pada Kelinci (Orytolagus cuniculus) yang Terinfeksi Bakteri Staphylococcus aureus', Jurnal Ilmiah Farmasi, 2, 51-59.

Rochani, N., 2009, 'Uji Aktivitas Antijamur Ekstrak Daun Binahong (Anredera cordifolia (Tenore) Steenis) Terhadap Candida albicans Serta Skrining Fitokimianya', Fakultas Farmasi, Universitas Muhammadiyah Surakarta, Surakarta.

Robinson, T., 1995,Kandungan Organik Tumbuhan Tinggi. VI. Bandung: ITB, 725-730.

Yenti, Revi., dkk., 2011, Formulasi Krim Ekstrak Etanol Daun Kirinyuh (Euphatoriumodoratum. L) untuk Penyembuhan Luka, Majalah Kesehatan PharmaMedika. 3. 227-230. 